Supporting Information

\title{
Surface Restructuring of Supported Nano-Ceria for Improving Sulfur Resistance
}

\author{
Beom-Sik Kim, Junemin Bae, Hojin Jeong, Chanyeong Choe, and Hyunjoo Lee* \\ Department of Chemical and Biomolecular Engineering, Korea Advanced Institute of Science \\ and Technology, Daejeon 34141, Republic of Korea
}

Table of Contents:

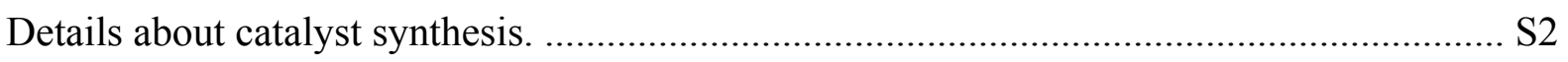

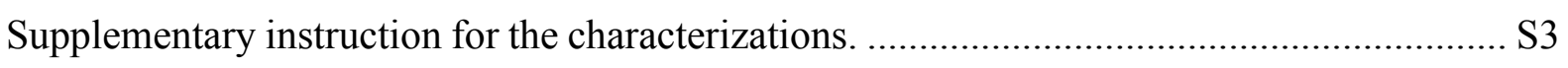

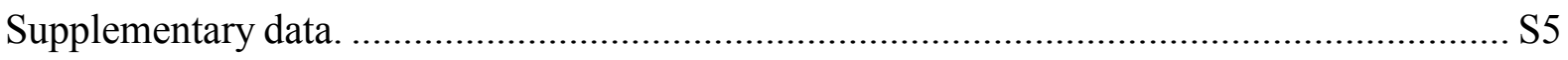

* Corresponding author. azhyun@kaist.ac.kr 


\section{Details about catalyst synthesis:}

The commercial $\gamma-\mathrm{Al}_{2} \mathrm{O}_{3}\left(99.97 \%\right.$, Alfa Aesar) was first activated under a $10 \% \mathrm{H}_{2} / \mathrm{N}_{2}$ flow at $350{ }^{\circ} \mathrm{C}$ for $1 \mathrm{~h}$ to create unsaturated penta-coordinated $\mathrm{Al}^{3+}\left(\mathrm{Al}^{3+}{ }_{\text {penta }}\right)$ sites. ${ }^{19}$ The activated $\gamma$ alumina is denoted as ' $\mathrm{AA}_{2} \mathrm{O}_{3}$ '. Then, the activated $\gamma-\mathrm{Al}_{2} \mathrm{O}_{3}$ powders were impregnated with an aqueous solution of $\mathrm{Ce}\left(\mathrm{NO}_{3}\right)_{3} \cdot 6 \mathrm{H}_{2} \mathrm{O}(99.99 \%$, Kanto Chemical), leading to the formation of nano-sized $\mathrm{CeO}_{2}$ species on the $\mathrm{Al}^{3+}{ }_{\text {penta }}$ sites. The target loading of $\mathrm{Ce}$ was $20 \mathrm{wt} \%$. The solution was vigorously stirred at room temperature for $1 \mathrm{~h}$. Subsequently, the solution was heated until the water evaporated completely. The resulting powder was dried in an oven at 80 ${ }^{\circ} \mathrm{C}$ overnight to remove any remaining water and finally calcined in static air at $500{ }^{\circ} \mathrm{C}$ for $5 \mathrm{~h}$. This material is denoted as ' $\mathrm{CeO}_{2} / \mathrm{rAl}_{2} \mathrm{O}_{3}$ '. The $\mathrm{CeO}_{2} / \mathrm{rAl}_{2} \mathrm{O}_{3}$ sample was hydrothermally treated at $750{ }^{\circ} \mathrm{C}$ for $25 \mathrm{~h}$ under the flow of $10 \%$ water vapor (balanced air). The temperature of hydrothermal treatment was varied from 650 to $850{ }^{\circ} \mathrm{C}$, and these materials are denoted as ' $\mathrm{CeO}_{2} / \mathrm{rAl}_{2} \mathrm{O}_{3}$ xHT' $(\mathrm{x}=650,750,850)$.

Pt was deposited on the support by the wet impregnation method. The aqueous solution including the desired amount of $\mathrm{H}_{2} \mathrm{PtCl}_{6} \cdot 6 \mathrm{H}_{2} \mathrm{O}(\leq 100 \%$, Sigma-Aldrich) was added to the support powder, and this slurry was stirred continually at $80{ }^{\circ} \mathrm{C}$ until the water evaporated completely. After impregnation, the sample was dried at $80^{\circ} \mathrm{C}$ overnight, and the dried powder was calcined in air at $500{ }^{\circ} \mathrm{C}$ for $1 \mathrm{~h}$. Finally, the calcined powder was reduced in $5 \% \mathrm{H}_{2} / \mathrm{N}_{2}$ at $500{ }^{\circ} \mathrm{C}$ for $1 \mathrm{~h}$. The target $\mathrm{Pt}$ loading was $0.5 \mathrm{wt} \%$. 


\section{Supplementary instruction for the characterizations:}

(1) General characterizations

The structural changes of catalysts were observed by transmission electron microscopy (TEM, Tecnai G2 F30 S-Twin, FEI), high-angle annular dark-field scanning TEM (HAADF-STEM, Titan cubed G2 60-300, FEI), X-ray diffractometer (XRD, Rigaku, $\mathrm{Cu} \mathrm{K \alpha}$ radiation) and $\mathrm{N}_{2}$ adsorption/desorption isotherms at $-196{ }^{\circ} \mathrm{C}$ (Tristar II 3020, Micromeritics). X-ray photoelectron spectroscopy (XPS) data were acquired using a K $\alpha$ XPS spectrometer (Thermo VG Scientific). The binding energies were calibrated using an advantageous C 1s peak at 284.8 $\mathrm{eV}$. The Ce $3 \mathrm{~d}$ XPS data consist of two sets of spin-orbital multiplets of $\mathrm{Ce} 3 \mathrm{~d}_{3 / 2}$ and $\mathrm{Ce} 3 \mathrm{~d}_{5 / 2}$ contributions; the peaks labeled $\mathrm{u}_{0}(889.3 \mathrm{eV}), \mathrm{u}^{\prime}(903.2 \mathrm{eV}), \mathrm{v}_{0}(881.6 \mathrm{eV})$, and v' $(884.9 \mathrm{eV})$ refer to $\mathrm{Ce}^{3+}$, while the peaks labeled u $(900.7 \mathrm{eV})$, u' $(907.5 \mathrm{eV}), \mathrm{u}$ ', $(916.7 \mathrm{eV}), \mathrm{v}(882.5$ $\mathrm{eV}), \mathrm{v}$ ' $(888.7 \mathrm{eV})$, and v', $(898.3 \mathrm{eV})$ correspond to $\mathrm{Ce}^{4+}$. For a quantitative estimation of $\mathrm{Ce}^{3+}$ in $\mathrm{CeO}_{2} / \mathrm{rAl}_{2} \mathrm{O}_{3}$, the ratio of $\mathrm{Ce}^{3+}$ in the total $\mathrm{Ce}$ content was estimated by comparing integrated areas of the peaks for the $\mathrm{Ce}^{3+}\left(\mathrm{u}_{0}, \mathrm{u}^{\prime}, \mathrm{v}_{0}, \mathrm{v}^{\prime}\right)$ and $\mathrm{Ce}^{4+}\left(\mathrm{u}, \mathrm{u}^{\prime}, \mathrm{u}^{\prime \prime}, \mathrm{v}, \mathrm{v}\right.$ ', and $\mathrm{v}^{\prime \prime}$ '). The following equation was used;

$$
C e^{3+}=\frac{A_{u_{0}}+A_{u^{\prime}}+A_{v_{0}}+A_{v^{\prime}}}{A_{u}+A_{u^{\prime \prime}}+A_{u^{\prime \prime \prime}}+A_{v}+A_{v^{\prime \prime}}+A_{v^{\prime \prime \prime}}+A_{u_{0}}+A_{u^{\prime}}+A_{v_{0}}+A_{v^{\prime}}}
$$

where $A_{i}$ is the integrated area of peak " $i$ ".

(2) Temperature-programmed desorption (TPD)

TPD experiments with $\mathrm{CO}_{2}$ or $\mathrm{SO}_{2}$ were performed on a BELCAT-B (MicrotracBEL) equipped with a mass spectrometer (MS). The catalyst was pre-treated by flowing $50 \mathrm{sccm}$ of $5 \% \mathrm{O}_{2} / \mathrm{He}$ at $400{ }^{\circ} \mathrm{C}$ for $1 \mathrm{~h}$ and cooled to room temperature. Next, $10 \% \mathrm{CO}_{2} / \mathrm{He}$, or $1000 \mathrm{ppm} \mathrm{SO}_{2} / \mathrm{Ar}$ gas was flowed to the catalyst at room temperature for $1 \mathrm{~h}$. Then, the catalyst was treated under He flow at room temperature for $30 \mathrm{~min}$. Finally, the catalyst was heated to $900{ }^{\circ} \mathrm{C}\left(10^{\circ} \mathrm{C} / \mathrm{min}\right)$ under He flow. $\mathrm{CO}_{2}(\mathrm{~m} / \mathrm{z}=44)$ and $\mathrm{SO}_{2}(\mathrm{~m} / \mathrm{z}=64)$ in the outlet gas were analyzed by the MS detector.

(3) Diffuse reflectance infrared Fourier transform spectroscopy (DRIFTS)

To identify the carbonate and sulfate species, IR spectra of the samples were recorded on a FTIR spectrometer (Nicolet iS50, Thermo Scientific). The catalyst was mixed with $\mathrm{KBr}$ powder with a 1:7 weight ratio and finely ground. The mixed powder was placed in a sample cup and set inside a DRIFT cell. The DRIFTS cell was pre-heated under $5 \% \mathrm{O}_{2} / \mathrm{Ar}$ flow at $400{ }^{\circ} \mathrm{C}$ for 
$1 \mathrm{~h}$ and then cooled to room temperature before switching to Ar purging. Then the feed gas with probe molecules $\left(\mathrm{CO}_{2}\right.$ or $\left.\mathrm{SO}_{2}\right)$ was flowed at room temperature for $10 \mathrm{~min}$, and DRIFT spectra were collected under vacuum. 5\% $\mathrm{CO}_{2} / \mathrm{Ar}$ and $100 \mathrm{ppm} \mathrm{SO}_{2} / \mathrm{Ar}$ flows were introduced for $\mathrm{CO}_{2}$ and $\mathrm{SO}_{2}$ adsorptions, respectively.

\section{(4) Pulsed CO chemisorption}

The Pt dispersion on the samples was determined by a pulsed $\mathrm{CO}$ adsorption technique, which was modified from the method of Takeguchi et al. (Appl. Catal. A 2005, 293, 91-96; ACS Catal. 2017, 7, 7097-7105) The size of Pt nanoparticles was estimated from the Pt dispersion. First, the catalyst $\left(30 \mathrm{mg}\right.$ ) was heated under $5 \% \mathrm{O}_{2} / \mathrm{He}$ gas at $300{ }^{\circ} \mathrm{C}$ for $10 \mathrm{~min}$ and subsequently cooled to $50{ }^{\circ} \mathrm{C}$, where the sample was purged with $\mathrm{He}$ gas for $5 \mathrm{~min}$. Next, the sample was heated under a $5 \% \mathrm{H}_{2} /$ Ar flow to $200{ }^{\circ} \mathrm{C}$. After it was cooled to $50{ }^{\circ} \mathrm{C}$, the sample was exposed to the gas flows in the following sequence: (i) $\mathrm{He}$ (5 min); (ii) $5 \% \mathrm{O}_{2} / \mathrm{He}$ (5 min); (iii) $\mathrm{CO}_{2}$ (10 min); (iv) $\mathrm{He}(20 \mathrm{~min})$; (v) $5 \% \mathrm{H}_{2} / \mathrm{Ar}$ (5 min). $\mathrm{CO}_{2}$ was injected to form carbonates on the ceria surface, in order to prevent over-estimating Pt dispersion. Finally, $\mathrm{CO}$ was pulsed every 1 min under a stream of He until the adsorption of CO onto the sample was saturated.

\section{(5) Catalytic test}

$\mathrm{CO}$ oxidation was performed in a U-shaped quartz glass fixed-bed reactor at atmospheric pressure. The catalyst $(50 \mathrm{mg})$ was charged inside the reactor. The reactor was purged with 100 sccm of Ar gas at $100{ }^{\circ} \mathrm{C}$ for $1 \mathrm{~h}$ and cooled to room temperature under Ar flow. A total 100 sccm of feed gas was introduced with $1 \% \mathrm{CO}$ and $1 \% \mathrm{O}_{2}$ in Ar balance for $\mathrm{CO}$ oxidation. The reactor was heated to the target reaction temperature with a ramping rate of $5{ }^{\circ} \mathrm{C} / \mathrm{min}$ and was held at that temperature for $18 \mathrm{~min}$ to reach a steady state. The product gases were monitored with an online gas chromatography (GC, Younglin GC 6500 system) equipped with a packed bed carboxen 1000 column (75035, SUPELCO, $15 \mathrm{ft} . \times 1 / 8$ in. $\times 2.1 \mathrm{~mm}$ ), a thermal conductivity detector (TCD), a capillary column (GS-GASPRO, Agilent Technologies, $30 \mathrm{~m}$ $\times 0.32 \mathrm{~mm}$ ), and a flame ionization detector (FID). In order to assess the sulfur resistance of the catalysts, sulfation-desulfation test was carried out through the following steps: (Step 1) standard $\mathrm{CO}$ oxidation with $1 \% \mathrm{CO}$ and $1 \% \mathrm{O}_{2}$ in Ar balance without $\mathrm{SO}_{2}$ at $100{ }^{\circ} \mathrm{C}$; (step 2) with 20 ppm $\mathrm{SO}_{2}$ at $100{ }^{\circ} \mathrm{C}$ for $180 \mathrm{~min}$; (step 3) without $\mathrm{SO}_{2}$ at $100{ }^{\circ} \mathrm{C}$ for $90 \mathrm{~min}$; (step 4) with $2 \% \mathrm{H}_{2} / \mathrm{Ar}, 0$ ppm $\mathrm{SO}_{2}$ at $650{ }^{\circ} \mathrm{C}$ for $1 \mathrm{~h}$; (step 5) under standard conditions without $\mathrm{SO}_{2}$ at $100{ }^{\circ} \mathrm{C}$. 


\section{Supplementary data:}
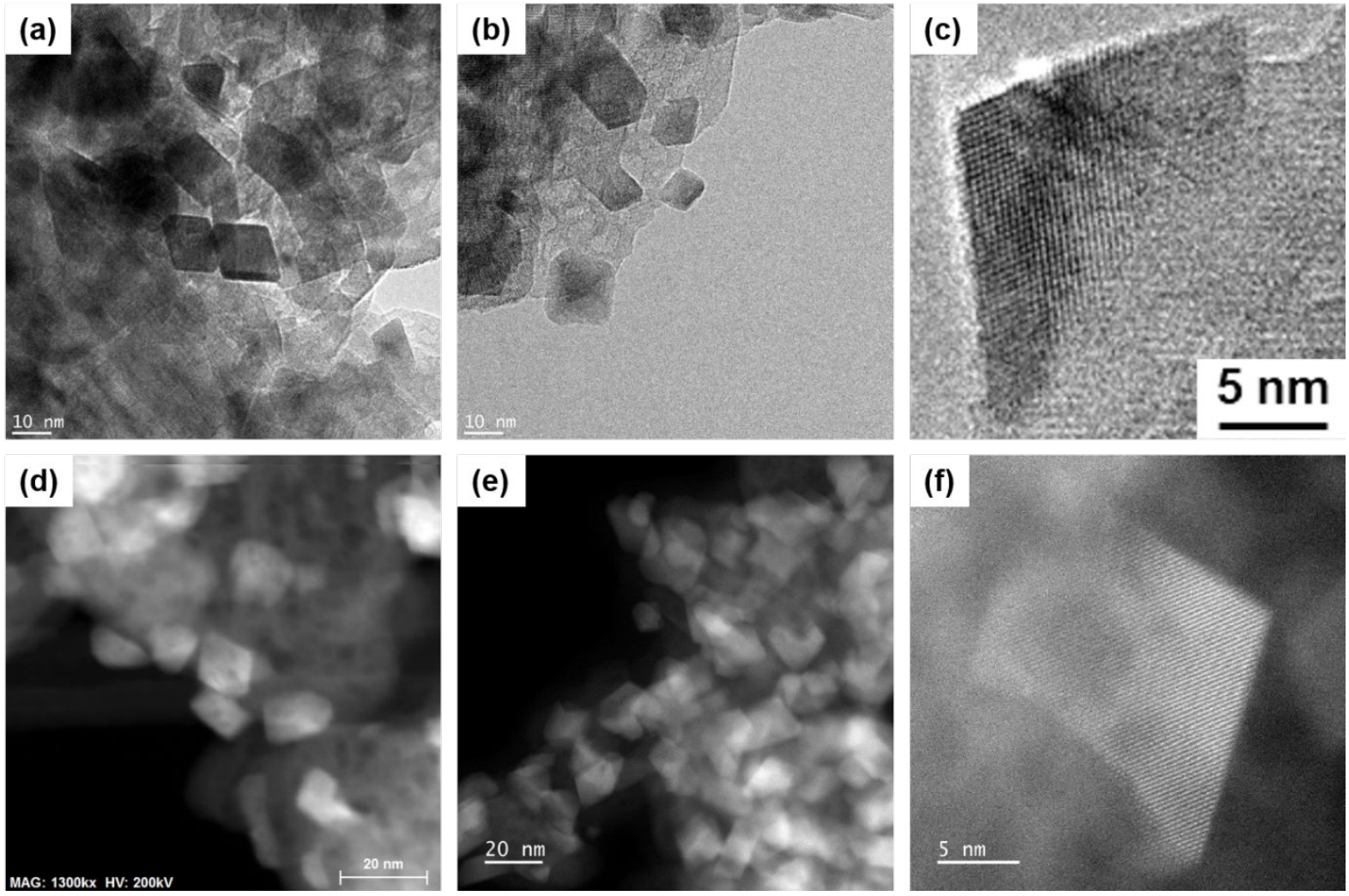

Figure S1. Additional (a-c) HR-TEM images and (d-f) HAADF-STEM images of $\mathrm{CeO}_{2} / \mathrm{rAl}_{2} \mathrm{O}_{3}$ - $750 \mathrm{HT}$ supports obtained after hydrothermal treatment at $750{ }^{\circ} \mathrm{C}$ for $25 \mathrm{~h}$. 


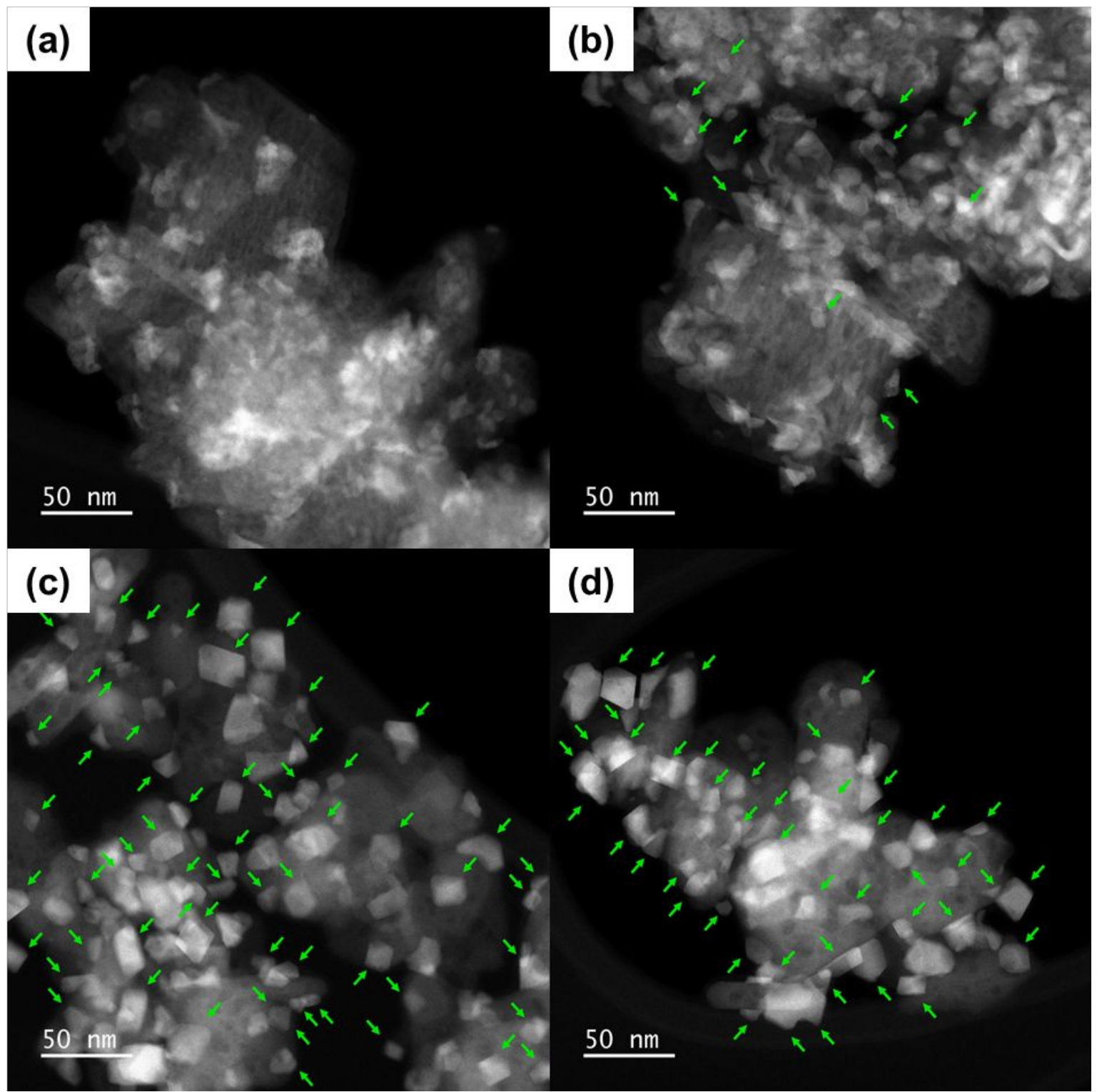

Figure S2. HAADF-STEM images of (a) $\mathrm{CeO}_{2} / \mathrm{rAl}_{2} \mathrm{O}_{3}$, (b) $\mathrm{CeO}_{2} / \mathrm{rAl}_{2} \mathrm{O}_{3}$ 650HT, (c) $\mathrm{CeO}_{2} / \mathrm{rAl}_{2} \mathrm{O}_{3}{ }_{2} 750 \mathrm{HT}$, and (d) $\mathrm{CeO}_{2} / \mathrm{rAl}_{2} \mathrm{O}_{3}$ 850HT. The bright green arrows indicate the nano-ceria with octahedral shape. 
Table S1. The counting results of nano-ceria with octahedral shape estimated from the HAADF-STEM images in Figure S2.

\begin{tabular}{cccc}
\hline Support & $\begin{array}{c}\text { Total number of } \\
\text { ceria paricles }\end{array}$ & $\begin{array}{c}\text { Number of } \\
\text { octahedral shape }\end{array}$ & $\begin{array}{c}\text { Percentage of } \\
\text { octahedral shape }\end{array}$ \\
\hline $\mathrm{CeO}_{2} / \mathrm{rAl}_{2} \mathrm{O}_{3}$ 650HT & 94 & 13 & $14 \%$ \\
$\mathrm{CeO}_{2} / \mathrm{rAl}_{2} \mathrm{O}_{3}$ 750HT & 87 & 62 & $71 \%$ \\
$\mathrm{CeO}_{2} / \mathrm{rAl}_{2} \mathrm{O}_{3} 850 \mathrm{HT}$ & 53 & 45 & $85 \%$ \\
\hline
\end{tabular}




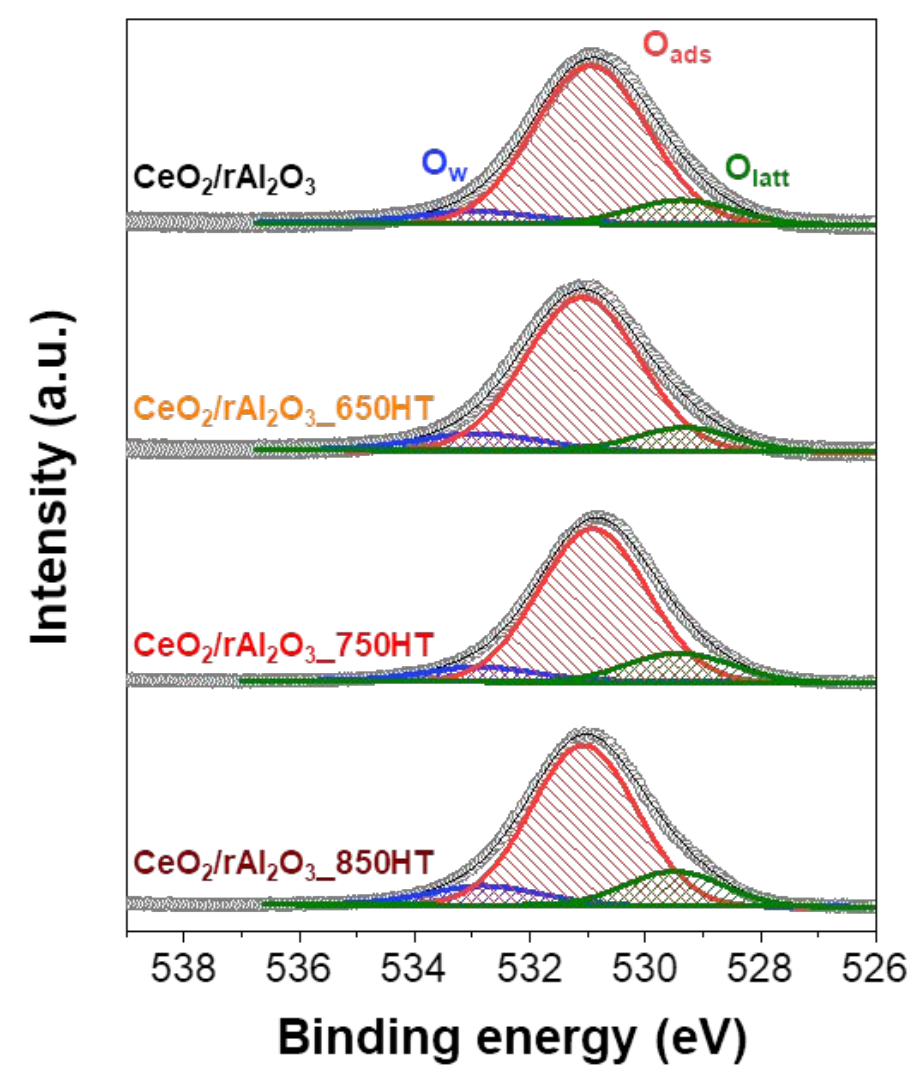

Figure S3. XPS O 1s spectra of $\mathrm{CeO}_{2} / \mathrm{rAl}_{2} \mathrm{O}_{3}$ supports. 
Table S2. Deconvolution results of O 1s XPS peaks shown in Figure S1. The amount of surface oxygen species $\left(\mathrm{O}_{\mathrm{ads}}\right)$ decreased upon hydrothermal treatment.

\begin{tabular}{ccccc}
\hline Catalyst & $\mathrm{O}_{\text {latt }}(\%)^{\mathrm{a}}$ & $\mathrm{O}_{\text {ads }}(\%)^{\mathrm{b}}$ & $\mathrm{O}_{\mathrm{w}}(\%)^{\mathrm{c}}$ & $\mathrm{O}_{\text {ads }} / \mathrm{O}_{\text {latt }}$ \\
\hline $\mathrm{CeO}_{2} / \mathrm{rAl}_{2} \mathrm{O}_{3}$ & 11.4 & 80.1 & 8.5 & 7.0 \\
$\mathrm{CeO}_{2} / \mathrm{rAl}_{2} \mathrm{O}_{3}$ 650HT & 12.0 & 77.5 & 10.6 & 6.5 \\
$\mathrm{CeO}_{2} / \mathrm{rAl}_{2} \mathrm{O}_{3}$ 750HT & 14.0 & 76.1 & 10.0 & 5.5 \\
$\mathrm{CeO}_{2} / \mathrm{rAl}_{2} \mathrm{O}_{3}$ 850HT & 15.0 & 74.3 & 10.7 & 5.0 \\
\hline
\end{tabular}

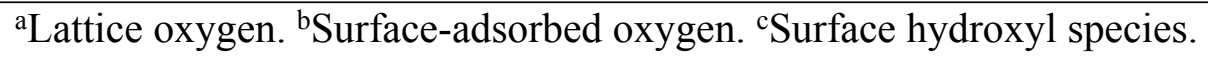




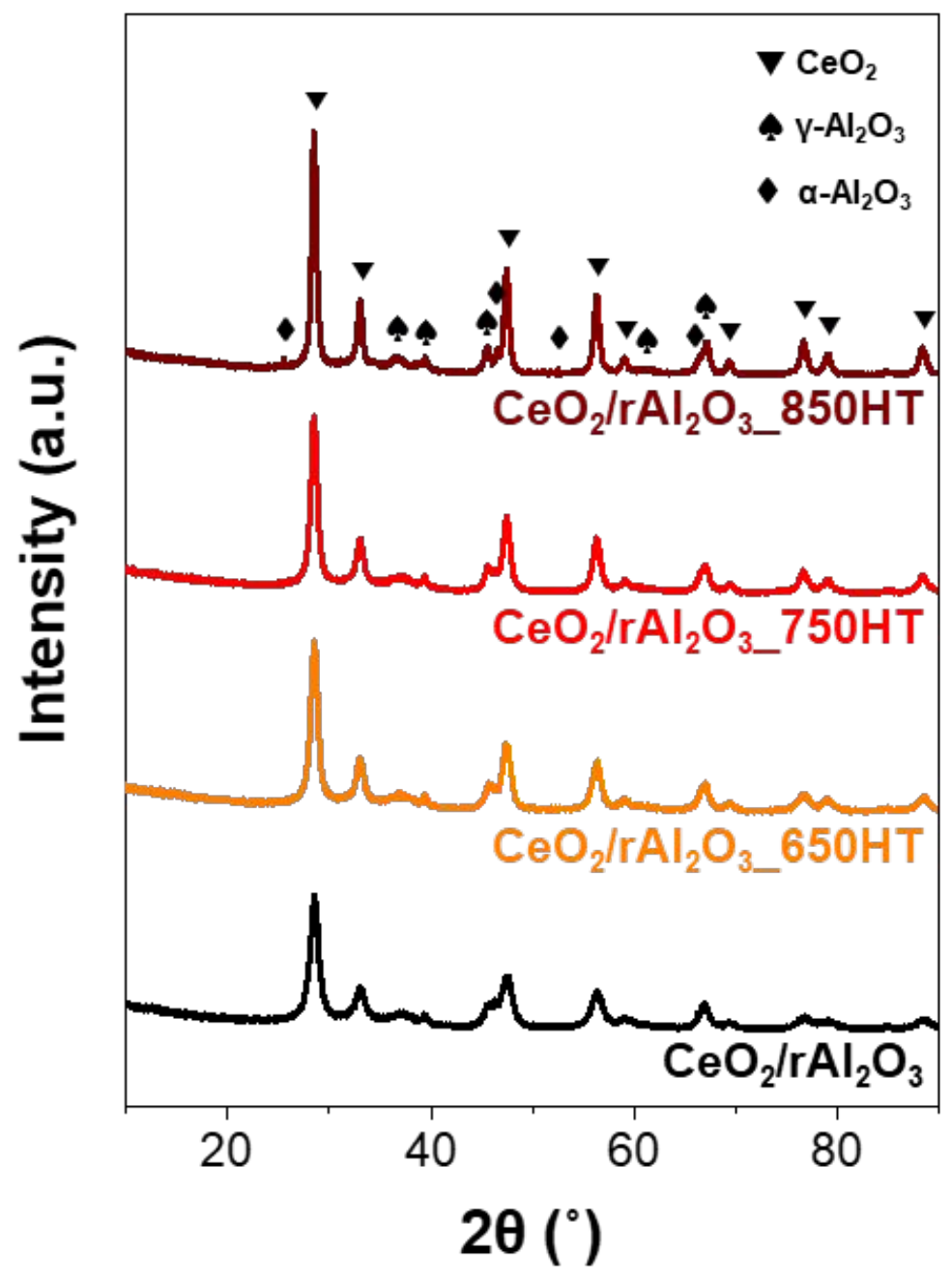

Figure S4. XRD patterns of the $\mathrm{CeO}_{2} / \mathrm{rAl}_{2} \mathrm{O}_{3}$ and $\mathrm{CeO}_{2} / \mathrm{rAl}_{2} \mathrm{O}_{3} \mathrm{xHT}\left(\mathrm{x}=650,750,850{ }^{\circ} \mathrm{C}\right)$ supports. The ceria domain size was estimated as 9.2, 13.7, 15.9, and $23.8 \mathrm{~nm}$ for the $\mathrm{CeO}_{2} / \mathrm{rAl}_{2} \mathrm{O}_{3}$ and $\mathrm{CeO}_{2} / \mathrm{rAl}_{2} \mathrm{O}_{3}$ xHT $\left(\mathrm{x}=650,750,850{ }^{\circ} \mathrm{C}\right)$, respectively, from $\mathrm{CeO}_{2}(111)$ peak at $28.5^{\circ}$. 
Table S3. BET surface area and the amount of $\mathrm{CO}_{2}$ released up to $700^{\circ} \mathrm{C}$ during $\mathrm{CO}_{2}$-TPD.

\begin{tabular}{cccc}
\hline Support & $\begin{array}{c}\text { BET Surface area } \\
\left(\mathrm{m}^{2} / \mathrm{g}\right)\end{array}$ & $\begin{array}{c}\mathrm{CO}_{2} \text { release up to } \\
700^{\circ} \mathrm{C} \text { TPD } \\
(\mu \mathrm{mol} / \mathrm{g})\end{array}$ & $\begin{array}{c}\mathrm{CO}_{2} \text { release up to } \\
700^{\circ} \mathrm{C} \mathrm{TPD} \\
\left(\mu \mathrm{mol} / \mathrm{m}^{2}\right)\end{array}$ \\
\hline $\mathrm{CeO}_{2} / \mathrm{rAl}_{2} \mathrm{O}_{3}$ & 63 & 130.1 & 2.1 \\
$\mathrm{CeO}_{2} / \mathrm{rAl}_{2} \mathrm{O}_{3} 650 \mathrm{HT}$ & 52 & 88.6 & 1.7 \\
$\mathrm{CeO}_{2} / \mathrm{rAl}_{2} \mathrm{O}_{3}$ 750HT & 48 & 65.3 & 1.4 \\
$\mathrm{CeO}_{2} / \mathrm{rAl}_{2} \mathrm{O}_{3} 850 \mathrm{HT}$ & 30 & 30.1 & 1.0 \\
\hline
\end{tabular}



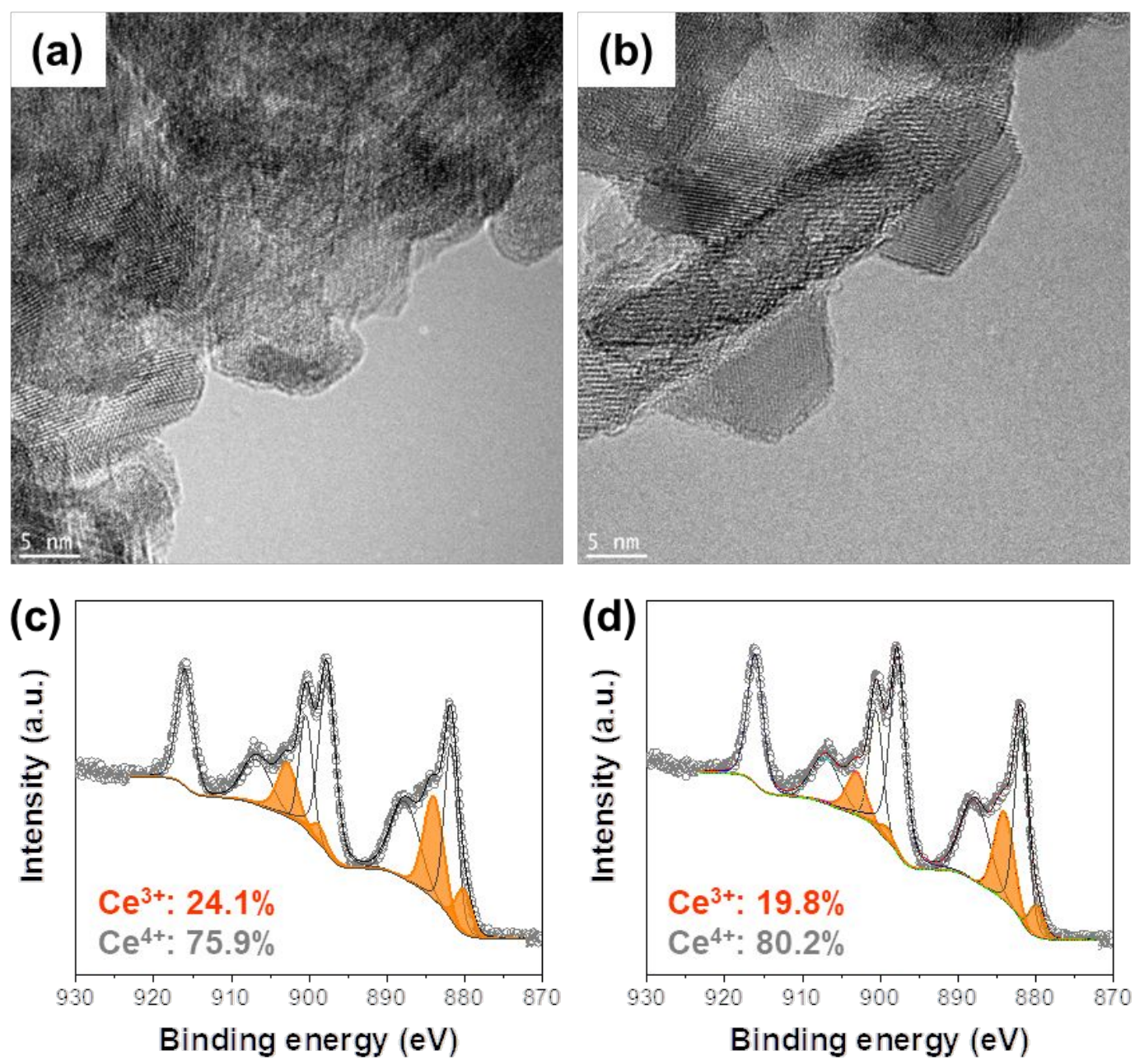

Figure S5. HR-TEM images and XPS Ce $3 \mathrm{~d}$ spectra of (a, c) as-made $\mathrm{CeO}_{2} / \mathrm{Al}_{2} \mathrm{O}_{3}$ and (b, d) $\mathrm{CeO}_{2} / \mathrm{Al}_{2} \mathrm{O}_{3}$ supports after hydrothermal treatment at $750{ }^{\circ} \mathrm{C}$ for $25 \mathrm{~h}$. The alumina did not undergo pre-activation procedure here. 


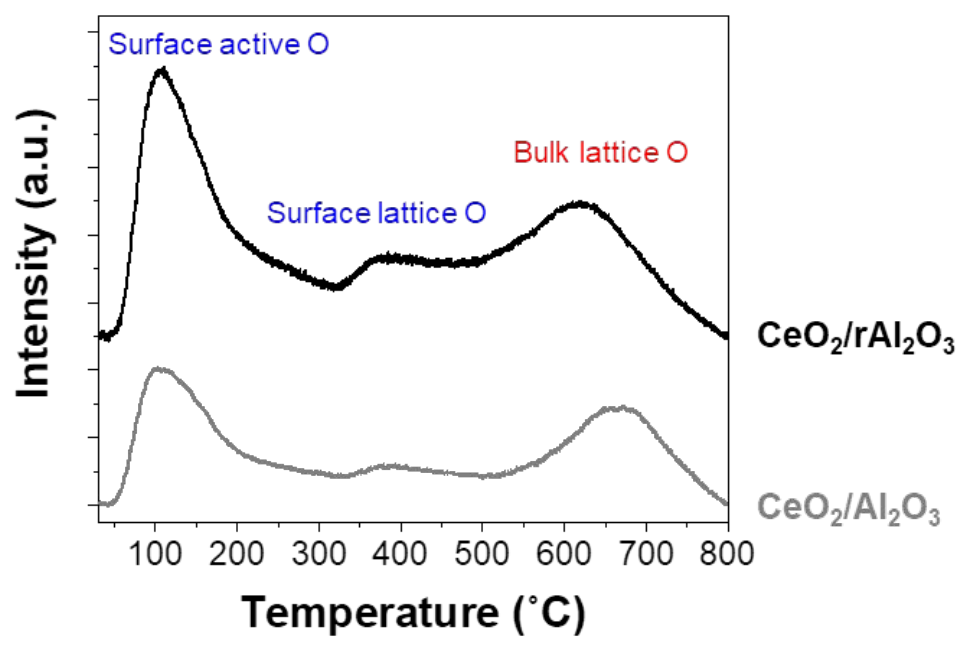

Figure S6. $\mathrm{O}_{2}$-TPD profiles performed after $\mathrm{O}_{2}$ was adsorbed by flowing $5 \% \mathrm{O}_{2}$ and $\mathrm{Ar}$ balance for $2 \mathrm{~h}$ at $25{ }^{\circ} \mathrm{C}$. The desorption peak below $300{ }^{\circ} \mathrm{C}$ is attributed to the surface active oxygen such as chemisorbed $\mathrm{O}_{2}{ }^{-}$and $\mathrm{O}^{-}$species, while the desorption peaks at $300-500{ }^{\circ} \mathrm{C}$ and above $500{ }^{\circ} \mathrm{C}$ correspond to surface lattice oxygen and bulk lattice oxygen, respectively

(Mol. Catal. 2019, 467, 9-15; Appl. Catal. B 2013, 142-143, 677-683). 
Table S4. Surface oxygen ratio estimated from $\mathrm{O}_{2}$-TPD results in Figure S6.

\begin{tabular}{ccc}
\hline Support & $\begin{array}{c}\text { Surface oxygen (surface active oxygen } \\
+ \text { surface lattice oxygen) }(\%)\end{array}$ & Bulk lattice oxygen (\%) \\
\hline $\mathrm{CeO}_{2} / \mathrm{rAl}_{2} \mathrm{O}_{3}$ & 67.7 & 32.3 \\
$\mathrm{CeO}_{2} / \mathrm{Al}_{2} \mathrm{O}_{3}$ & 55.0 & 45.0 \\
\hline
\end{tabular}




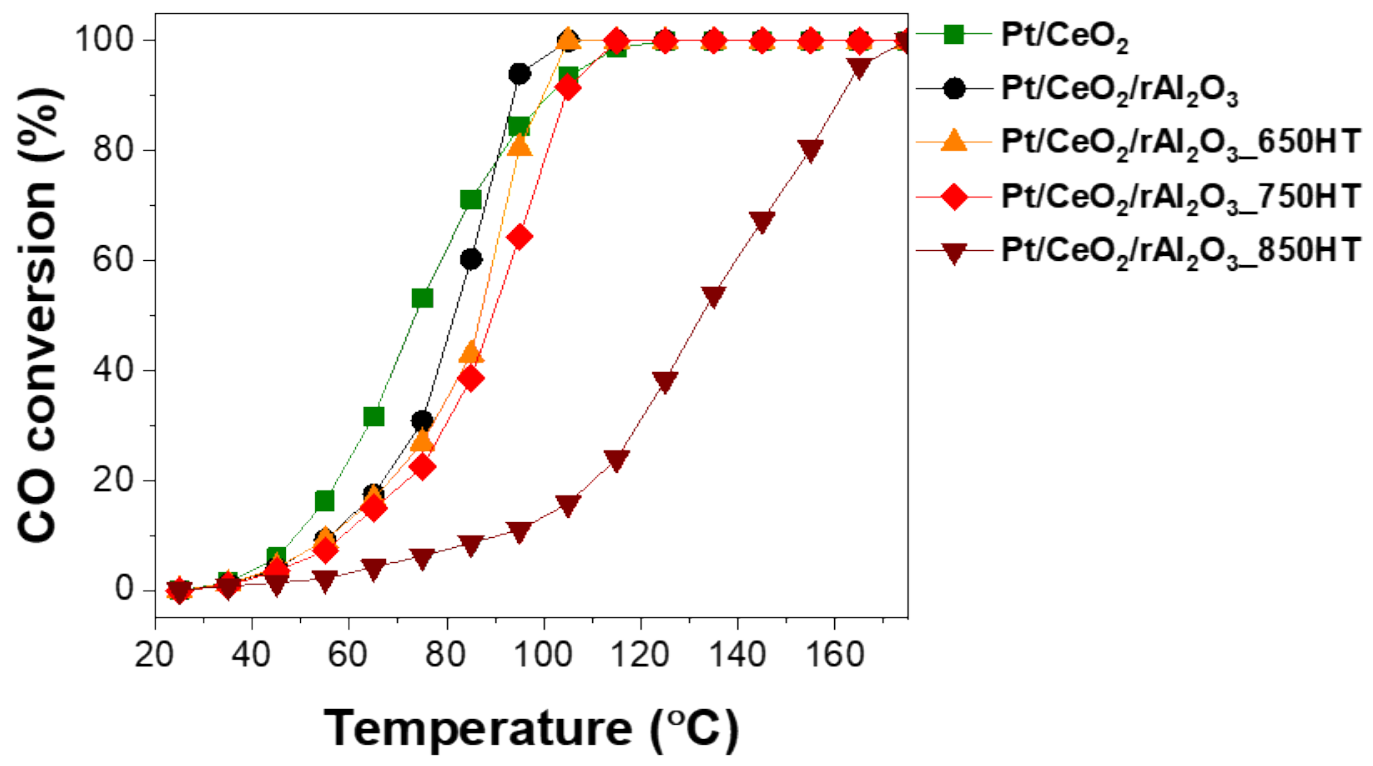

Figure S7. $\mathrm{CO}$ oxidation light-off curves of the Pt-loaded $\mathrm{CeO}_{2} / \mathrm{rAl}_{2} \mathrm{O}_{3}$ catalysts. $1 \% \mathrm{CO}$ and $1 \% \mathrm{O}_{2}$ (Ar balance) were flowed. 


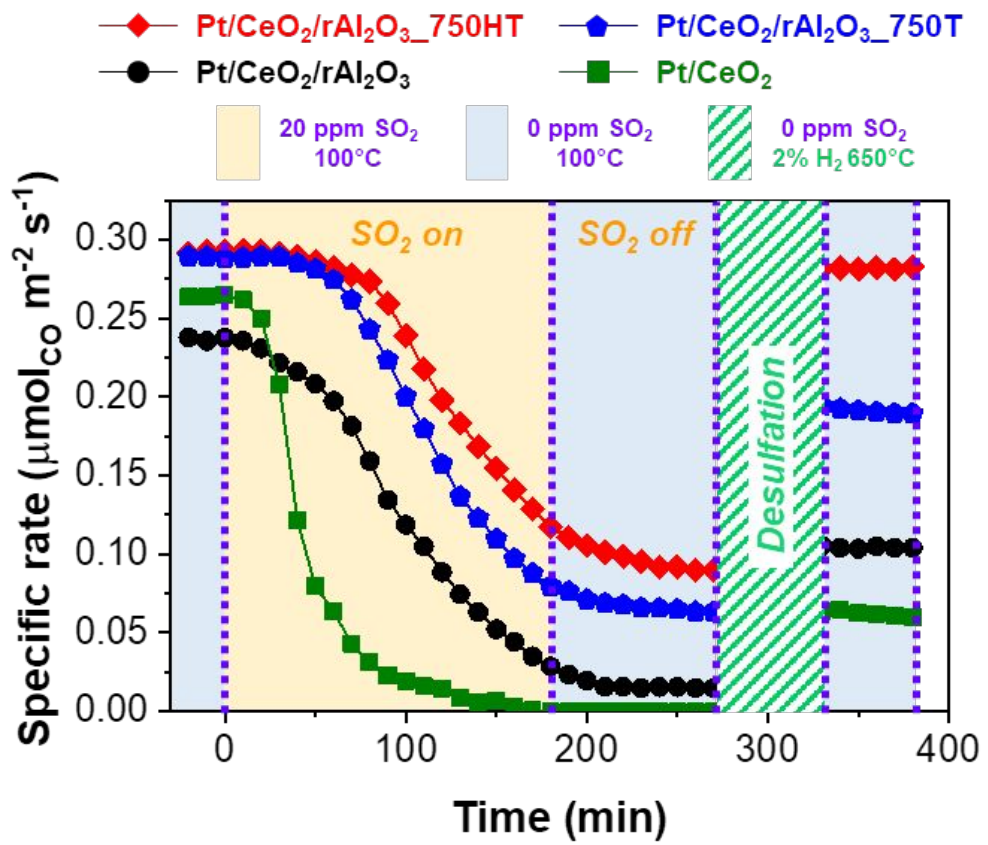

Figure S8. Specific rates normalized by catalyst surface area over the catalysts as a function of time on stream. 


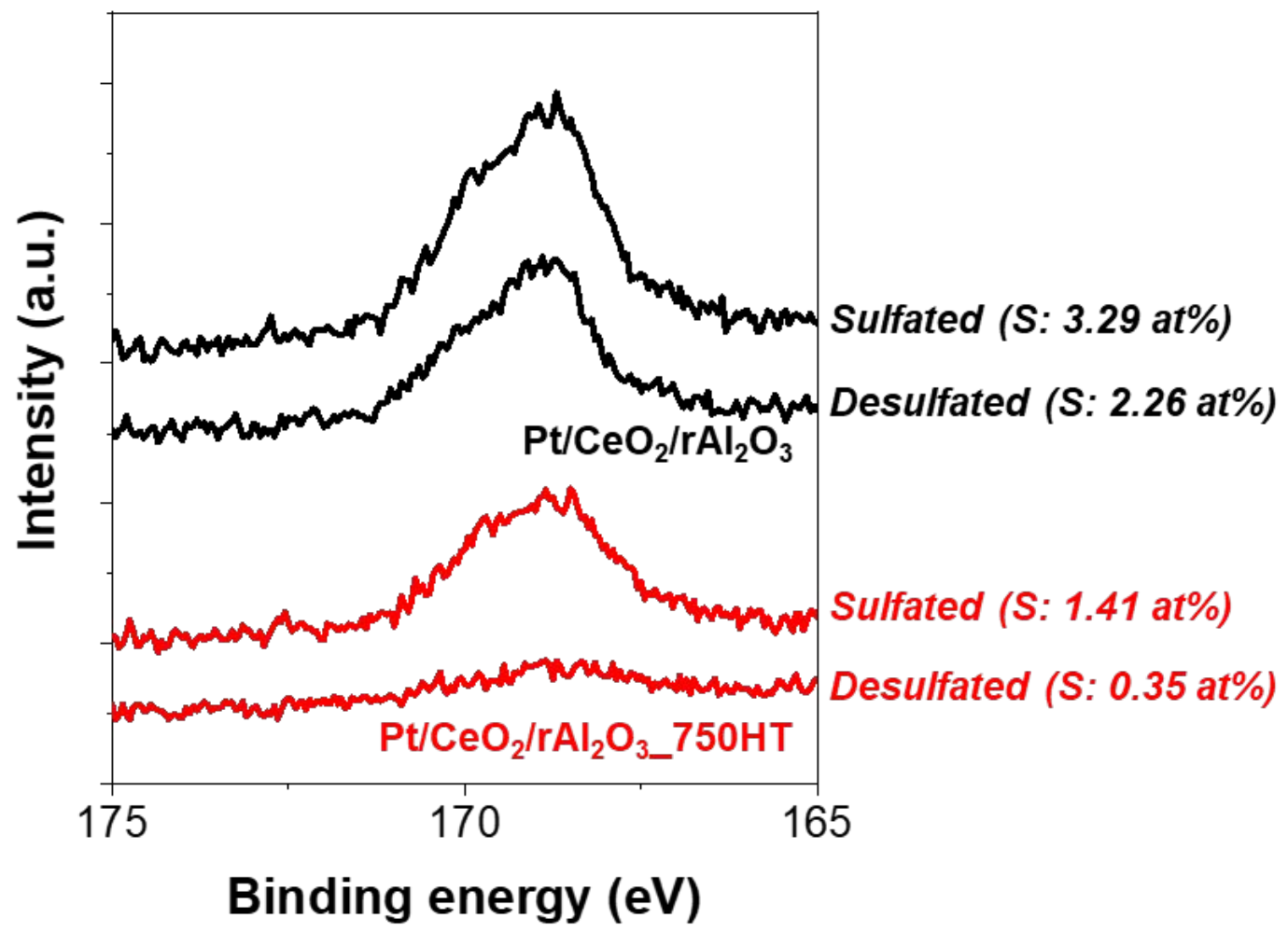

Figure S9. XPS S $2 p$ data of $\mathrm{Pt} / \mathrm{CeO}_{2} / \mathrm{rAl}_{2} \mathrm{O}_{3}$ and $\mathrm{Pt} / \mathrm{CeO}_{2} / \mathrm{rAl}_{2} \mathrm{O}_{3}$ 750HT catalysts after sulfation and desulfation at $650{ }^{\circ} \mathrm{C}$. 

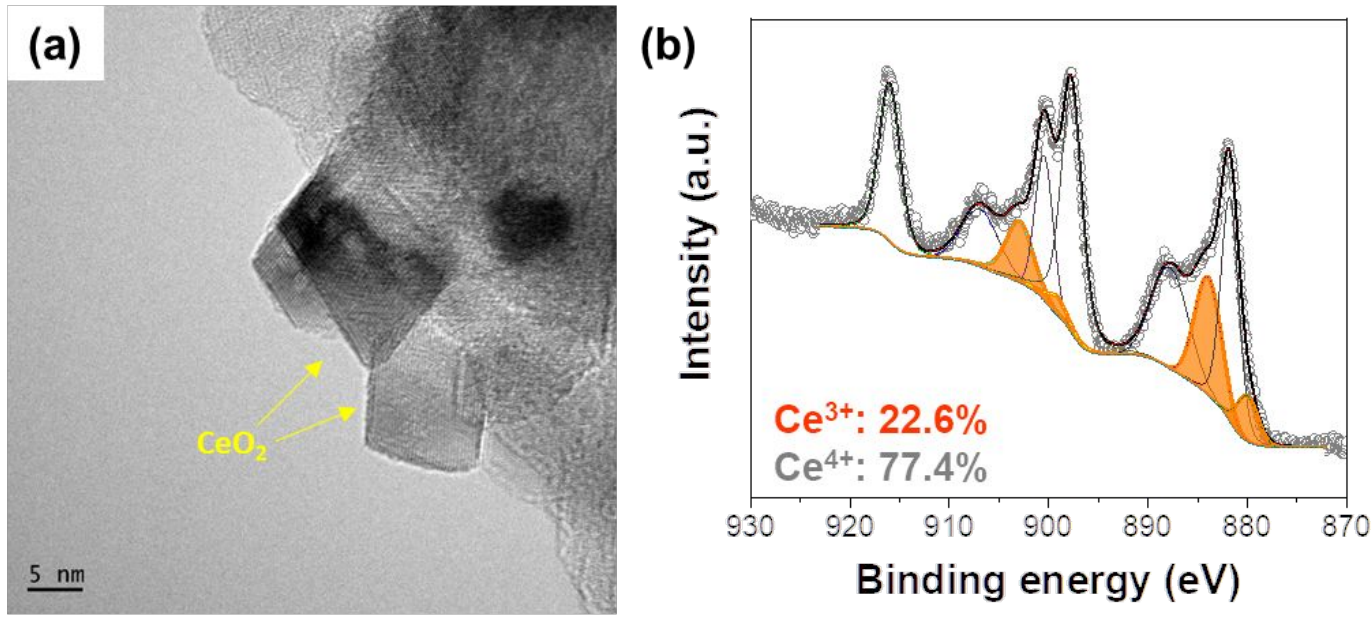

Figure S10. (a) HR-TEM image and (b) XPS Ce 3d spectrum of $\mathrm{CeO}_{2} / \mathrm{rAl}_{2} \mathrm{O}_{3}$ 750T support, which was treated thermally without steam at $750{ }^{\circ} \mathrm{C}$. 

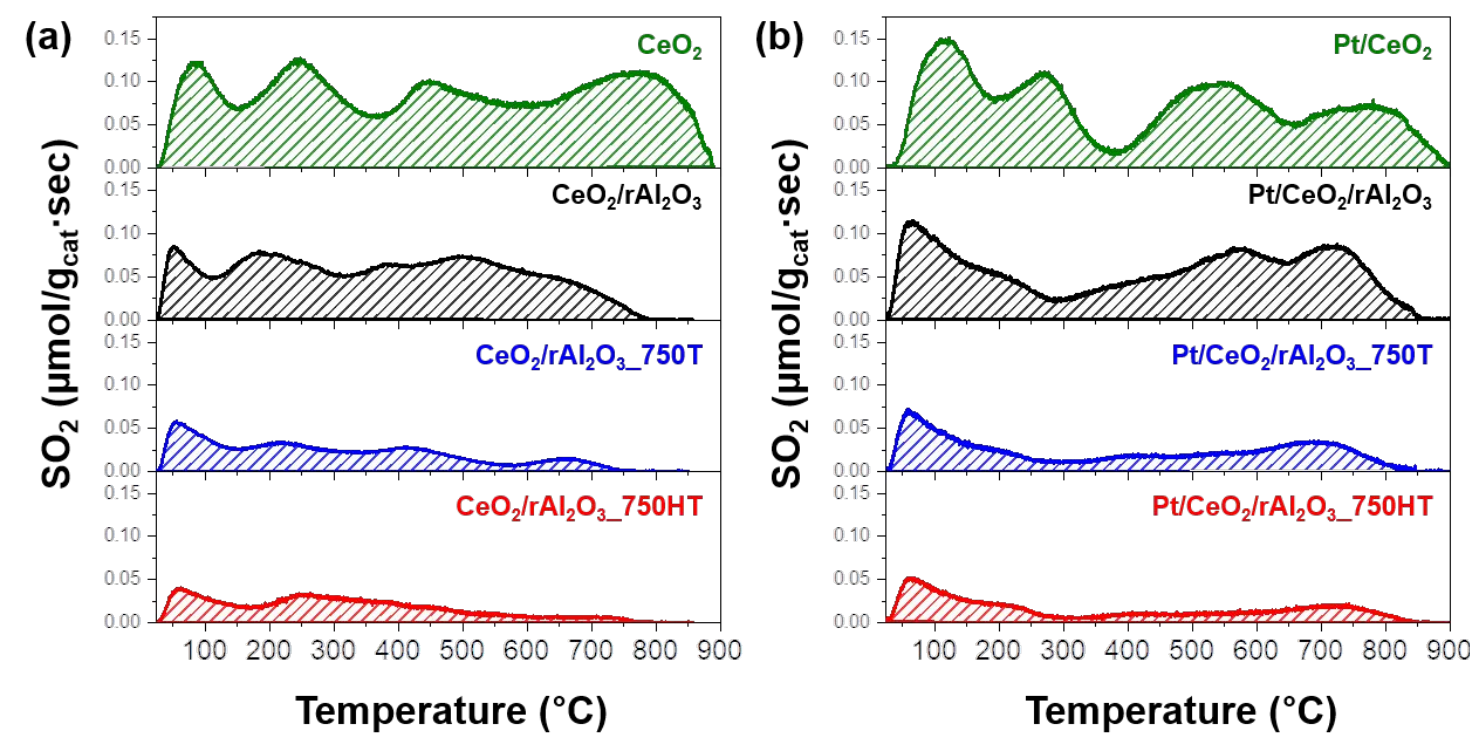

Figure S11. $\mathrm{SO}_{2}$-TPD profiles of (a) Pt-free and (b) Pt-loaded catalysts after $\mathrm{SO}_{2}$ was adsorbed on each catalyst by flowing $1000 \mathrm{ppm}$ of $\mathrm{SO}_{2}$ (Ar balance) for $1 \mathrm{~h}$ at $30{ }^{\circ} \mathrm{C}$. 
Table S5. BET surface area and the amount of $\mathrm{SO}_{2}$ released up to $900^{\circ} \mathrm{C}$ during $\mathrm{SO}_{2}-\mathrm{TPD}$.

\begin{tabular}{cccc}
\hline Catalyst & $\begin{array}{c}\text { BET Surface area } \\
\left(\mathrm{m}_{2} / \mathrm{g}\right)\end{array}$ & $\begin{array}{c}\mathrm{SO}_{2} \text { release up to } \\
900^{\circ} \mathrm{C} \text { TPD } \\
(\mu \mathrm{mol} / \mathrm{g})\end{array}$ & $\begin{array}{c}\mathrm{SO}_{2} \text { release up to } \\
900^{\circ} \mathrm{C} \text { TPD } \\
\left(\mu \mathrm{mol} / \mathrm{m}^{2}\right)\end{array}$ \\
\hline $\mathrm{CeO}_{2}$ & 53 & 295.2 & 5.6 \\
$\mathrm{CeO}_{2} / \mathrm{rAl}_{2} \mathrm{O}_{3}$ & 63 & 170.8 & 2.7 \\
$\mathrm{CeO}_{2} / \mathrm{rAl}_{2} \mathrm{O}_{3}$ 750T & 50 & 67.8 & 1.4 \\
$\mathrm{CeO}_{2} / \mathrm{rAl}_{2} \mathrm{O}_{3} 750 \mathrm{HT}$ & 48 & 53.8 & 1.1 \\
\hline $\mathrm{Pt}_{2} / \mathrm{CeO}_{2}$ & 51 & 305.3 & 6.0 \\
$\mathrm{Pt}_{2} \mathrm{CeO}_{2} / \mathrm{rAl}_{2} \mathrm{O}_{3}$ & 60 & 183.1 & 3.0 \\
$\mathrm{Pt} / \mathrm{CeO}_{2} / \mathrm{rAl}_{2} \mathrm{O}_{3} 750 \mathrm{~T}$ & 47 & 66.7 & 1.4 \\
$\mathrm{Pt} / \mathrm{CeO}_{2} / \mathrm{rAl}_{2} \mathrm{O}_{3} 750 \mathrm{HT}$ & 45 & 53.2 & 1.2 \\
\hline
\end{tabular}




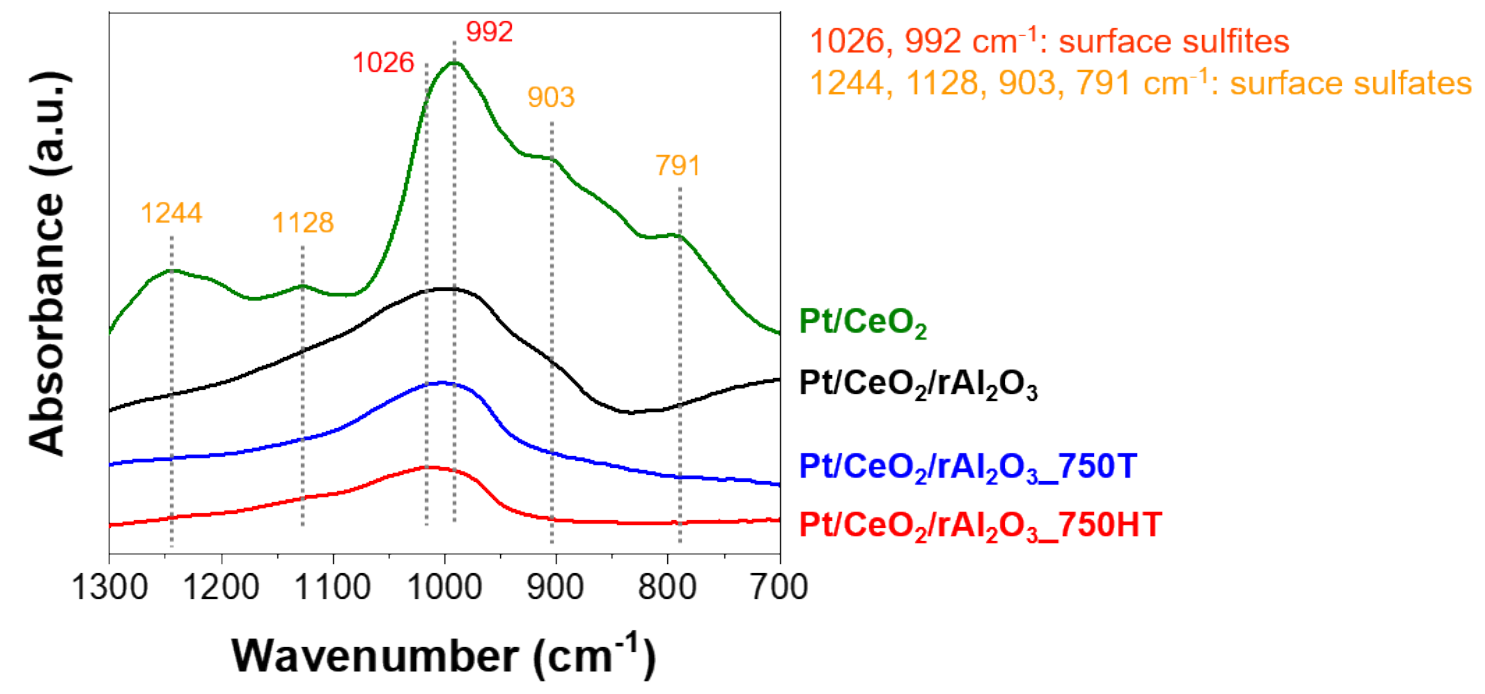

Figure S12. $\mathrm{SO}_{2}$-DRIFT spectra of the catalysts after $\mathrm{SO}_{2}$ was adsorbed on each catalyst by flowing $100 \mathrm{ppm} \mathrm{SO}_{2} / \mathrm{Ar}$ for $10 \mathrm{~min}$ at room temperature. 
Table S6. Pt dispersion measured by CO chemisorption and Pt particle size estimated from the Pt dispersion

\begin{tabular}{ccc}
\hline Catalyst & Pt dispersion $(\%)$ & Pt particle size $(\mathrm{nm})$ \\
\hline $\mathrm{Pt} / \mathrm{CeO}_{2} / \mathrm{rAl}_{2} \mathrm{O}_{3}$ & 79.2 & 1.4 \\
$\mathrm{Pt} / \mathrm{CeO}_{2} / \mathrm{rAl}_{2} \mathrm{O}_{3}$ 750HT & 76.3 & 1.5 \\
$\mathrm{Pt} / \mathrm{CeO}_{2} / \mathrm{rAl}_{2} \mathrm{O}_{3} 750 \mathrm{~T}$ & 75.0 & 1.5 \\
$\mathrm{Pt} / \mathrm{CeO}_{2}$ & 76.8 & 1.5 \\
\hline
\end{tabular}




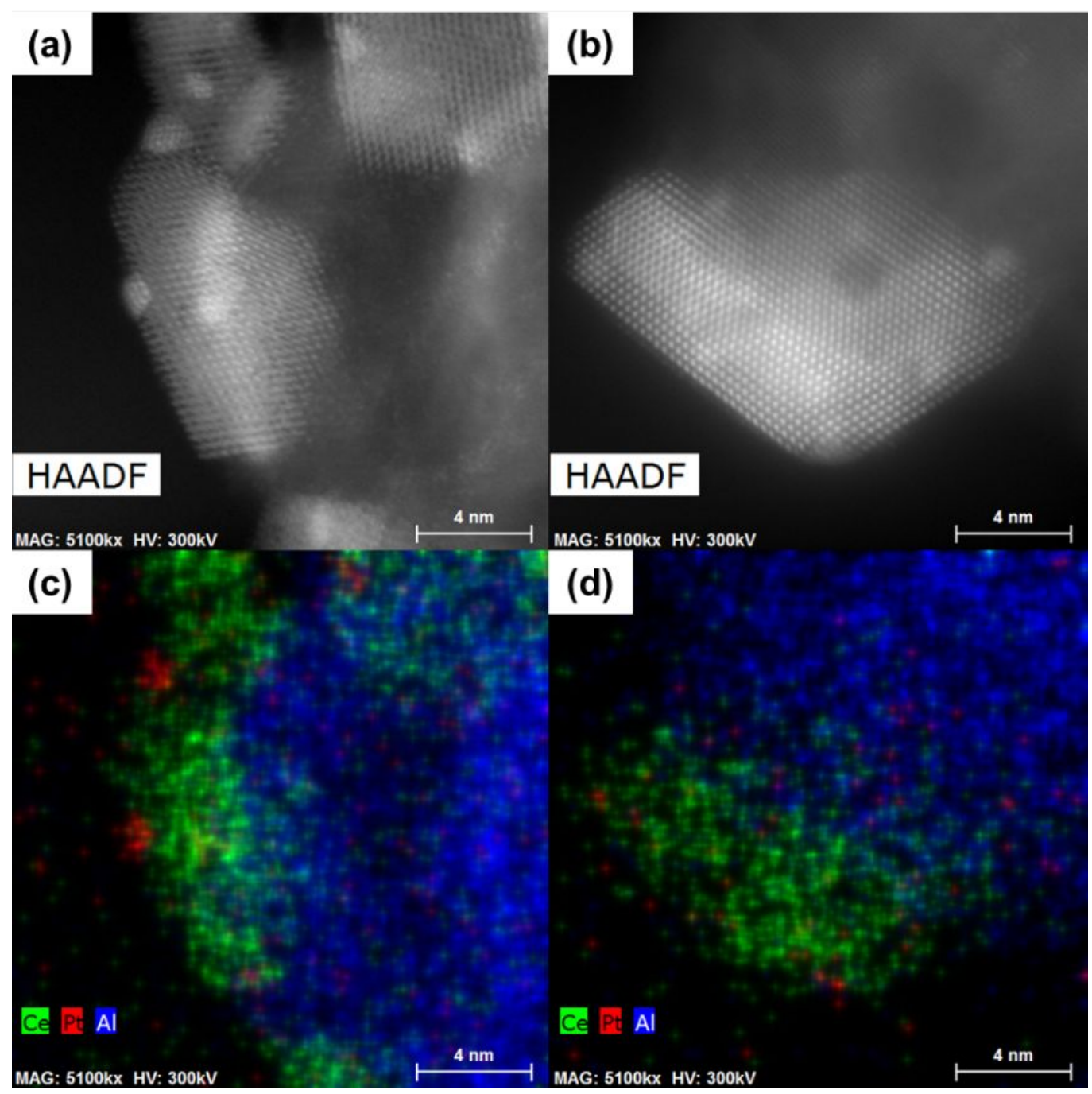

Figure S13. HAADF-STEM images of the (a) $\mathrm{Pt} / \mathrm{CeO}_{2} / \mathrm{rAl}_{2} \mathrm{O}_{3}$ and (b) $\mathrm{Pt} / \mathrm{CeO}_{2} / \mathrm{rAl}_{2} \mathrm{O}_{3}{ }_{7} 750 \mathrm{HT}$, and (c, d) their corresponding EDS mapping images. 


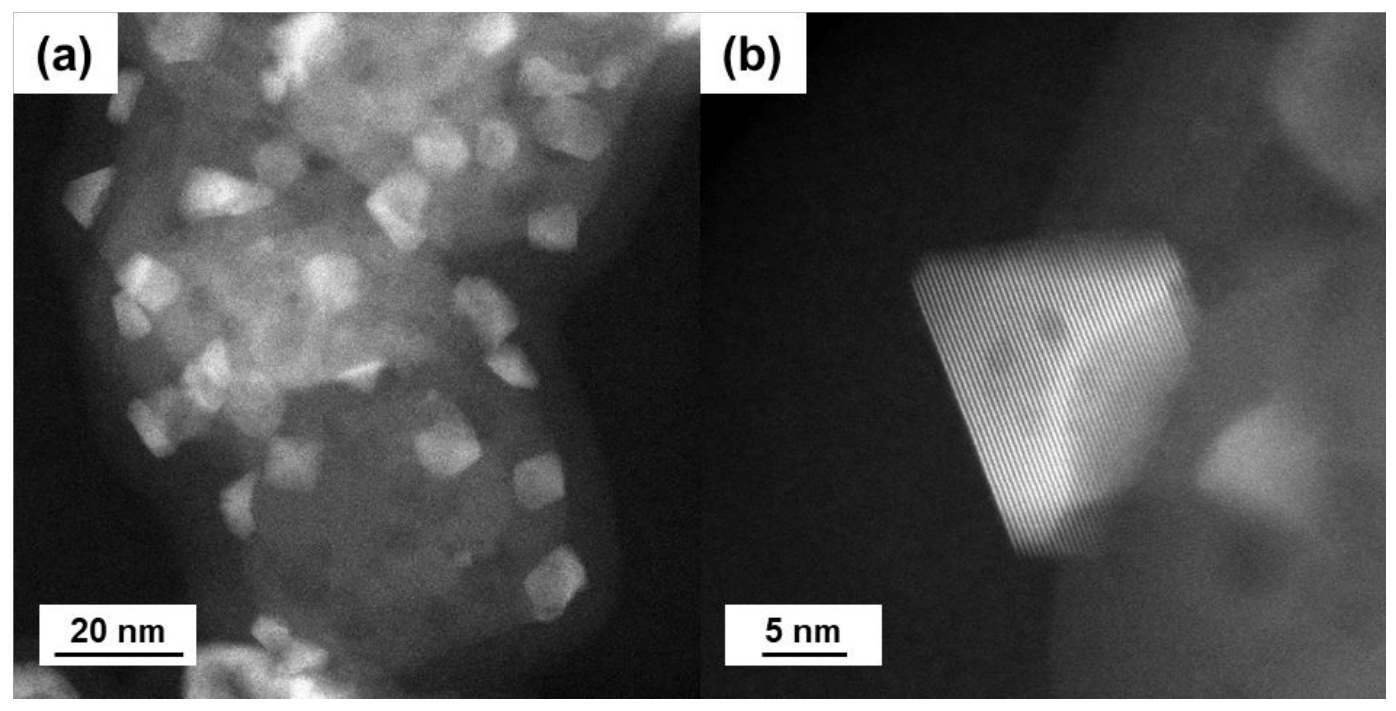

Figure S14. (a, b) HAADF-STEM images of $\mathrm{Pt} / \mathrm{CeO}_{2} / \mathrm{rAl}_{2} \mathrm{O}_{3}-750 \mathrm{HT}$ catalyst obtained after 4 th run of sulfation-desulfation cycle. 


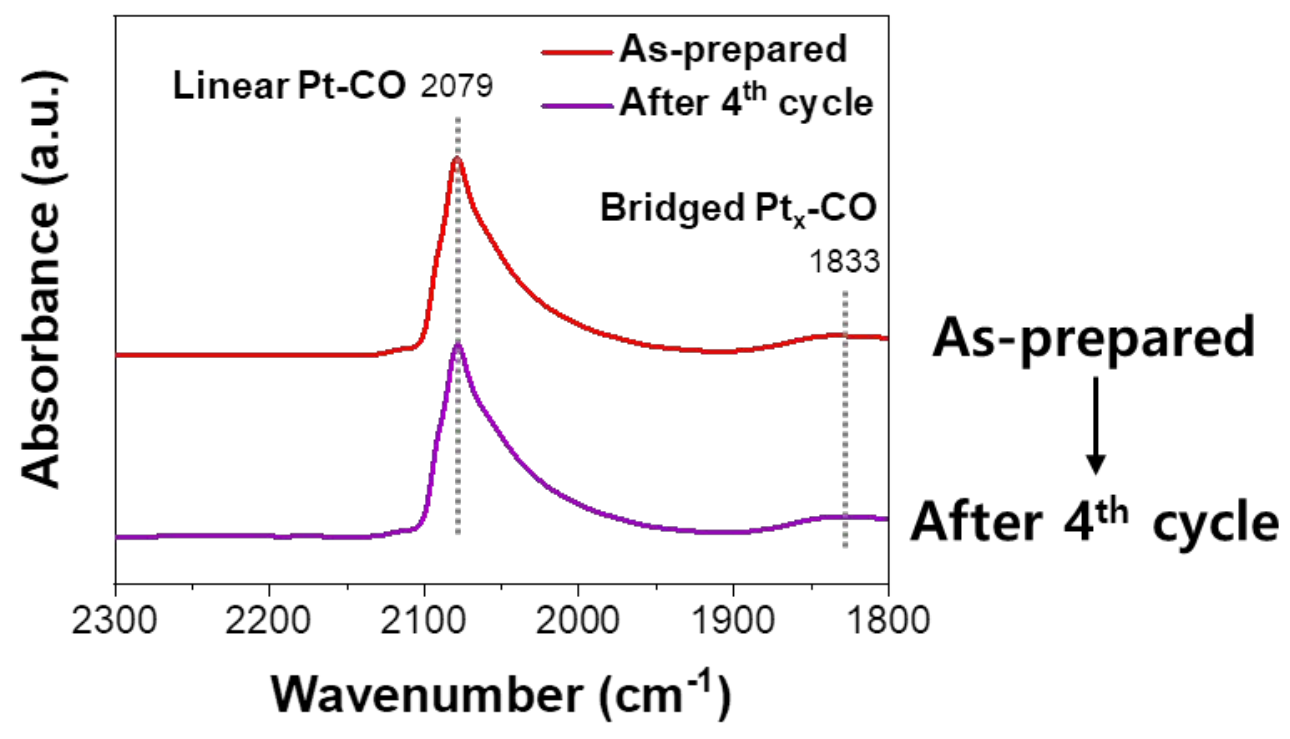

Figure S15. CO-DRIFT spectra of $\mathrm{Pt} / \mathrm{CeO}_{2} / \mathrm{rAl}_{2} \mathrm{O}_{3}$ - $750 \mathrm{HT}$ catalyst before reaction and after 4 th run of sulfation-desulfation cycle. 
Table S7. Pt dispersion and particle size of $\mathrm{Pt} / \mathrm{CeO}_{2} / \mathrm{rAl}_{2} \mathrm{O}_{3}$ - $750 \mathrm{HT}$ catalyst before reaction and after 4 th run of sulfation-desulfation cycle.

\begin{tabular}{ccc}
\hline $\mathrm{Pt} / \mathrm{CeO}_{2} / \mathrm{rAl}_{2} \mathrm{O}_{3} 750 \mathrm{HT}$ & Pt dispersion $(\%)$ & Pt particle size $(\mathrm{nm})$ \\
\hline As-prepared & 76.3 & 1.5 \\
After 4th cycle & 70.2 & 1.6 \\
\hline
\end{tabular}

